\title{
Toward an integrated route to the vernonia allenes and related sesquiterpenoids
}

\author{
Da Xu, Michael A. Drahl and Lawrence J. Williams*
}

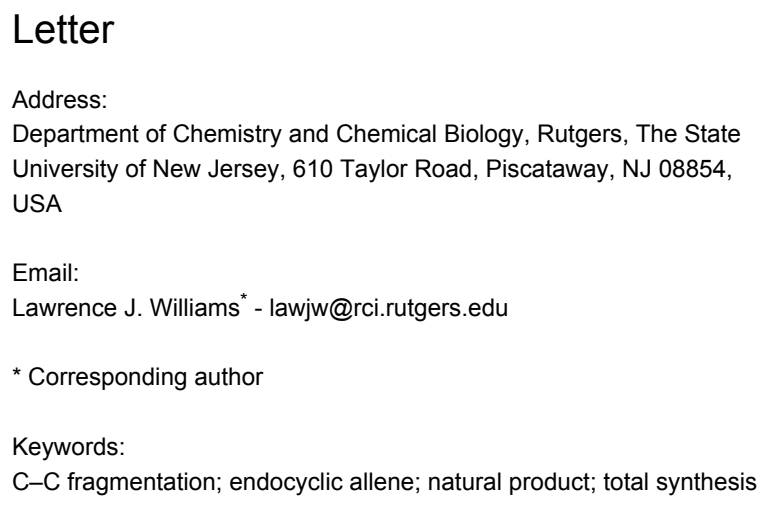

Beilstein J. Org. Chem. 2011, 7, 937-943.

doi:10.3762/bjoc.7.104

Received: 03 May 2011

Accepted: 09 June 2011

Published: 05 July 2011

This article is part of the Thematic Series "Allene chemistry".

Guest Editor: K. M. Brummond

(c) 2011 Xu et al; licensee Beilstein-Institut. License and terms: see end of document.

\begin{abstract}
The synthesis of a model endocyclic allene related to the vernonia allenes is described. Fragmentation of a suitable decalin derivative gave the simplified germacrane scaffold. Computational analysis of this and related substrates provides insight into the stereoelectronic requirements of $\mathrm{C}-\mathrm{C}$ fragmentation. The overall strategy to access these and other sesquiterpenes and the key steps in the present sequence are also discussed.
\end{abstract}

\section{Introduction}

Well over 150 allene-containing natural products are known [1-5]. Among these, intriguing complex structures were assigned by Bohlmann and co-workers to isolates from the aerial parts of Vernonia species collected mainly from northern Brazil about 30 years ago (1-3, Figure 1) [6-8]. These bicyclic germacranolides are the only known endocyclic allenecontaining natural products. Interestingly, no synthetic studies of these complex natural products have been reported, perhaps in part due to the limited number of routes for cyclic allene construction that are sufficiently mild to effect allene formation in complex settings [9-16].

Our interest in the vernonia allenes was motivated in part by a desire to identify, and to simplify access to, useful bioactive compounds with these sequiterpenoid structures, examples of which are given in Figure 1 (4-12) [17-23]. Although many of these isolates have not been characterized with regard to their biological function, there is a rich variety of germacranes from terrestrial plants, algae, and insect pheromones that purportedly have anticancer, antifungal, and antibiotic activity, among others. For example, parthenolide (6) has anti-inflammatory and anti-hyperalgesic effects and induces apoptosis of human acute myelogenous leukemia stem and progenitor cells [24]; eupaheliangolide A (7) is cytotoxic to human oral epidermoid (KB), cervical epitheloid (Hela), and liver (hepa59T/VGH) carcinoma cells [21]; sinugibberodiol (10) exhibits beneficial multidrug resistance properties in mammalian tumor cells [25]; eleganolactone B (11) inhibits the proliferation of the HL-60 
<smiles>CC(=O)OCC1=C2C(C)=C=CC/C(C)=C/[C@H]2OC1=O</smiles>

1<smiles>CC1C(=O)O[C@@H]2CC3(C)OC3C[C@H](O)[C@]3(C)O[C@H]3CC12</smiles>

carabrolactone A 5

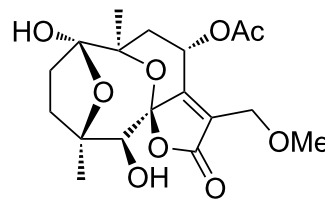

spicatolide G

9

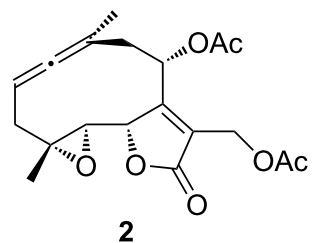

vernonia allenes (1-3)

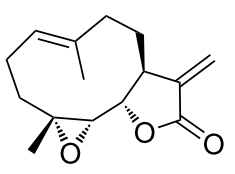

parthenolide

6

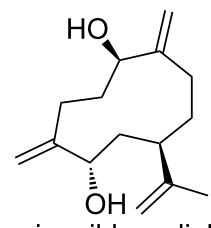

sinugibberodiol

10

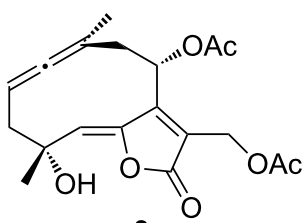

3<smiles>C=C1C(=O)O/C1=C/C(C)=C/C(=O)/C=C(/C)C(=O)OC1CC(C)(O)C=C(C)C1=O</smiles>

eupaheliangolide $\mathrm{A}$

7<smiles>C=C1C(=O)O[C@@H]2C=C(C)C3(O)CCC(=C)C3(O)[C@@H](O)[C@H]12</smiles>

eleganolactone $B$

11

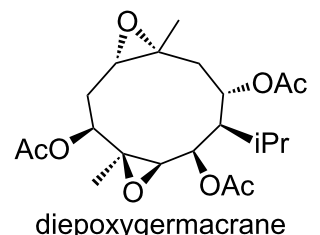

4<smiles>C[C@@H]1C[C@H]2O[C@H](CC(=O)C1=O)C(CO)=C1OC(=O)C(CO)=C12</smiles>

potamopholide

8<smiles></smiles>

salonitenolide ester

12

Figure 1: Known natural endocyclic allenes and related germacranes.

human promyelocytic leukemia cell line in a dose-dependent manner [26], and ester derivatives of salonitenolide 12 show promising antibacterial activity [27].

We have initiated a study that aims to integrate the chemical syntheses of compounds in this structure space into a single, late-stage-divergent, route [28]. A pluripotent route that would enable direct access to a broad range of these targets would be useful and would offer advantages over single-target routes, especially in terms of overall step economy. Given the difficulties associated with the stereoselective preparation of endocyclic allenes, and the fact that such structures are largely unexplored, we focused on the vernonia allenes. Moreover, we expected that such allenes contain the coded reactivity to access many sesquiterpenoid variants, especially in light of new methods of transforming allenes to diverse motifs [29-37]. Herein we report our efforts toward this goal with a short syn- thesis of a model 10-membered endocyclic allene of type $\mathbf{1 4}$ (Scheme 1).

\section{Results and Discussion}

Advanced intermediates with a high degree of unsaturation have greater potential use in an integrated routing strategy than more highly oxidized products, since not all targets in the group of compounds of interest share identical oxidation states or patterns. Recently, we reported the synthesis of 9- and 10 -membered cyclopolyenes [28,38], including a new stereospecific allene synthesis via $\mathrm{C}-\mathrm{C}$ fragmentation. This transformation appears well-suited for access to the vernonia targets and related compounds [15]. The method relies on suitably functionalized vinyl triflates [39-41]. In general, C-C fragmentation reactions appear to be sensitive to the precise structure of the cyclic system involved, and small, apparently minor, structural changes may severely retard the reaction [38]. For<smiles>[Y]C1=C([Y])[C@@]2(O)[C@@H]([Y4])CC=C([OH2+])[C@@]2([Z7])CC1[Z]</smiles>

13<smiles>[X]C(=O)C1=C(CC)C([Y4])CC=CC1C</smiles> 


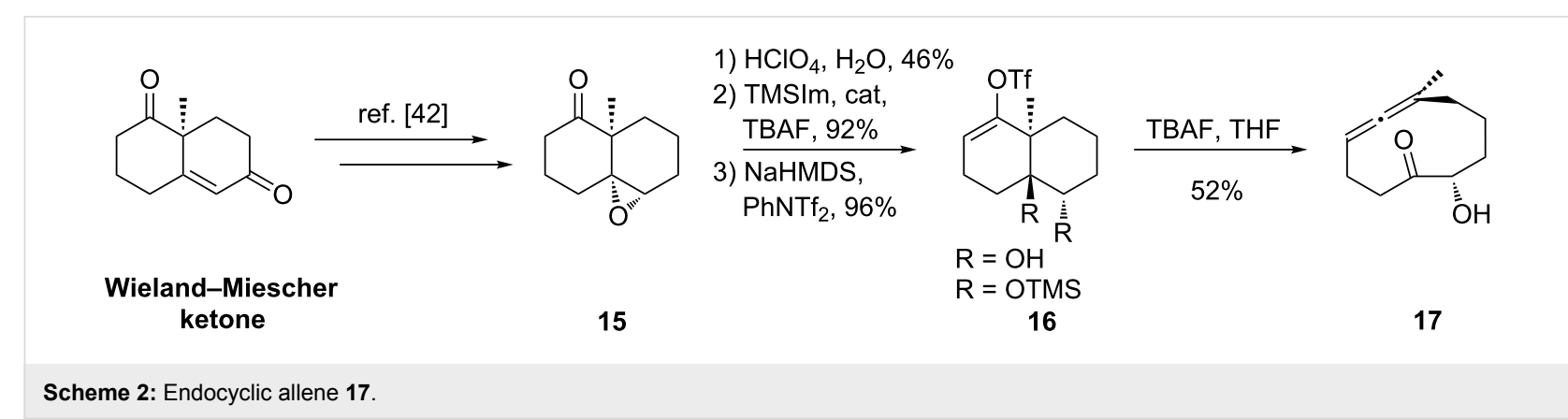

example, in our original disclosure, endocyclic allene 17 was formed from trans-decalin derivative $\mathbf{1 6}$ by way of the known compound 15 (Scheme 2) [42]. However, the vinyl triflate (16, $\mathrm{R}=\mathrm{OH})$ resisted fragmentation under standard basic conditions, whereas, the silyl ether (16, R = OTMS) underwent smooth fragmentation upon exposure to TBAF.

The ideal orientation for the two bonds that cleave in a $\mathrm{C}-\mathrm{C}$ fragmentation reaction is antiperiplanar [43-46]. However, to our knowledge, the minimum torsion angle required for fragmentation is not known, and no computational mechanistic study on these reactions has appeared as a guide in this regard. Admittedly, there are distinct differences between fragmentation and substitution; nevertheless, by analogy to $\mathrm{S}_{\mathrm{N}} 2$ reactions, $\mathrm{C}-\mathrm{C}$ fragmentation substrates with angles significantly less than $180^{\circ}$ may fail due to inadequate relative orientation $[47,48]$. For our purposes, we aimed to identify a scaffold that would readily adopt the ideal, or near-ideal, stereoelectronic arrangement necessary for $\mathrm{C}-\mathrm{C}$ fragmentation, and yet, would have the potential to accept further structural modification without intrinsic change, should that become necessary or desirable.

Table 1 summarizes the ground state computational modeling of several $\mathrm{C}-\mathrm{C}$ fragmentation substrates. The Gaussian suite of programs, with the B3LYP functional and the 6-31G(d,p) basis set, was used to generate these data [49-60]. The hydroxy derivatives $\left(\mathrm{R} / \mathrm{R}^{\prime}=\mathrm{OH}\right)$ and the corresponding alkoxides in vacuum were taken together to approximate the torsion angle of the anion fragmentation precursors. The trans-decalin system of entry 1 (c.f. Scheme 2) is highly constrained. The relevant torsion angles are around $155^{\circ}$, thus deviate significantly from $180^{\circ}$. This is true for the mono anions II and III as well as the diol I. Interestingly however, the dianion does not represent a stable structure, and instead gives the endocyclic allene via fragmentation, as observed experimentally. Entry 2 shows a cisdecalin system. Low energy conformers were identified for these species [59]. The lowest energy conformer gave the greatest torsion angles $\left(\sim 175^{\circ}\right)$ for both the alcohol $\mathbf{V}$ and the alkoxide VI, and these approach $180^{\circ}$. For comparison purposes, the $c i s$-hydrindane derivative in entry 3 was also studied [38]. Analogous to entry 2, this system contains an unsaturated site adjacent to the hydroxy/alkoxide. The torsion angles of the scissile bonds for this entry are approximately $163^{\circ}$. Importantly, this compound is known to undergo base-

Table 1: Computed torsion angles for potential $\mathrm{C}-\mathrm{C}$ fragmentation
substrates.

aDFT: B3LYP functional, 6-31G(d,p) basis set. 
induced fragmentation to give the $(E)$-alkene in excellent yield [61]. Among the substituted variants we considered, we were intrigued by the cis-decalin derivative of entry 4 . The ester functionality was taken as a prototype for substitution at this position and represents the potential for both steric and electronic effects. In this case, although both compounds exhibit similar torsion angles $\left(\sim 175^{\circ}\right)$, there appears to be a significant difference between the orientation of the ester relative to the adjacent $\mathrm{C}-\mathrm{C}$ double bond. For the neutral $(\mathrm{R}=\mathrm{OH})$ compound, the ester is coplanar with the double bond, whereas the ester is twisted out of planarity for the alkoxide $\left(\mathrm{R}=\mathrm{O}^{-}\right)$. This appears to be an electrostatic influence. The behavior noted in entry 4 was not unique to the cis-decalin system and the analogous cis-hydrindane exhibits similar behavior (entry 5): The ester group of the hydroxy entry 5 is coplanar with the alkene, whereas the ester is twisted out of planarity for the alkoxide ( $R$ $\left.=\mathrm{O}^{-}\right)[62]$.

In light of the above data, we targeted compound 24 (c.f. 14, Scheme 1) to extend the $\mathrm{C}-\mathrm{C}$ fragmentation to cis-decalins and to provide an important model for our synthetic studies. This substrate should be able to adopt conformers with the proper orientation for fragmentation and may well tolerate substitution. Given the uncertainties associated with the computational analysis and the precise requirements for fragmentation, it was not clear that even this model compound would undergo $\mathrm{C}-\mathrm{C}$ fragmentation to give the corresponding endocyclic allene. Consequently, we aimed to prepare $\mathbf{2 4}$ by a direct and modular route.

Scheme 3 depicts a concise route to $\mathbf{2 4}$ and $\mathbf{2 5}$. Beginning with the commercially available diketone $\mathbf{1 8}$, acid promoted Michael addition with acrolein gave aldehyde 19. A two step procedure, via 20, was employed to obtain the $(Z)$-bromoolefin 21. Initially, we examined the direct formation of $\mathbf{2 1}$ via bromomethyltriphenylphosphonium bromide (Scheme 4). This reaction was inefficient and gave both the $(E)$ - and $(Z)$ bromoolefins as well as dibromoolefin 20. Bromo group scrambling under basic Wittig reaction conditions is known [63], and the usual procedure for Wittig reagent formation with slow addition of $\mathbf{1 9}(1 \mathrm{~h})$ gave $\mathbf{2 1}$ with the desired olefin geometry but with low selectivity and yield (see below). Rapid addition of $\mathbf{1 9}$

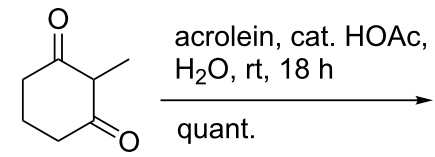

18

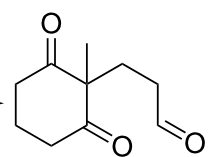

19

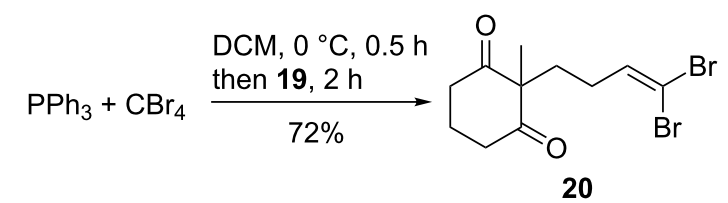

20

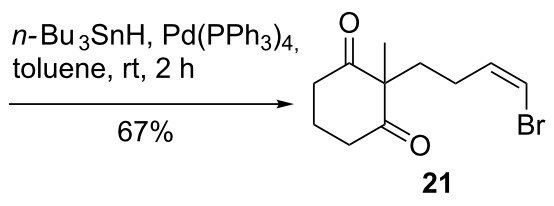

21

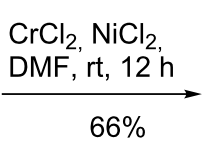

$66 \%$<smiles>O=C1CCCC2(O)C3CCCC12CC3</smiles>

TMSIm, cat. TBAF, THF, rt, $2 \mathrm{~h}$

$66 \%$

22<smiles>CO[C@]12C=CCC[C@]1(C)C(=O)CCC2</smiles>

23
NaHMDS, PhNTf $\mathrm{THF},-78^{\circ} \mathrm{C}$ to $0^{\circ} \mathrm{C}$, $1.5 \mathrm{~h}$ $79 \%$<smiles>CO[C@]12C=CCC[C@]1([18O])C([O+])=CCC2</smiles>

24

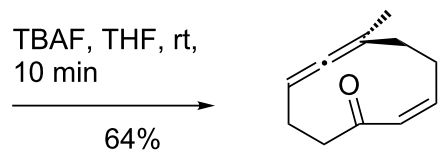

25

Scheme 3: Preparation of endocyclic allene 25.<smiles>CC1(CCC=O)C(=O)CCCC1=O</smiles>

19

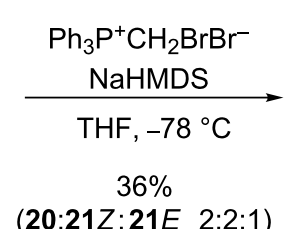

(20:21Z:21E 2:2:1)<smiles>CC1(CCC=C(Br)Br)C(=O)CCCC1=O</smiles>

20<smiles>O=C1CCCC(=O)C1CC/C=C\Br</smiles>

21 
( $1 \mathrm{~min}$ ), gave the desired product in $26 \%$ yield. The use of HMPA and/or iodomethyltriphenylphosphorane [64,65] was examined and failed to improve the reaction profile, as did varying the ratio of Wittig reagent relative to aldehyde (1-3 equiv), solvent (THF and toluene), and aldehyde concentration $(0.035-0.09 \mathrm{M})$. The yield of the reaction was low under all the conditions examined (13-26\%) [66]. The known behavior of bromomethyltriphenylphosphonium bromide under these strongly basic conditions, and the poor solubility of reactive species in THF, account for these results [63].

Alternatively, the $Z$-vinyl bromide $\mathbf{2 1}$ was readily obtained via dibromo-olefination of the aldehyde followed by selective removal of the $(E)$-bromide with $n-\mathrm{Bu}_{3} \mathrm{SnH}$ and catalytic $\mathrm{Pd}(0)$ $(\mathbf{1 9} \rightarrow \mathbf{2 1}$, Scheme 3). A simple sequence was utilized to furnish allene precursor 24: Thus 21 was converted to bicycle $\mathbf{2 2}$ under Nozaki-Hiyama-Kishi conditions [67,68], followed by silyl ether formation $(\rightarrow \mathbf{2 3}$ ) [69] and triflation to produce the desired decalin 24. There is little precedent for Nozaki-Hiyama-Kishi addition to ketones $[67,68]$, but the reaction proceeded without problems in serviceable yield. Brief exposure of $\mathbf{2 4}$ to anhydrous fluoride conditions effected clean $\mathrm{C}-\mathrm{C}$ fragmentation to give the functionalized 10 -membered endocyclic allene $\mathbf{2 5}$ in good yield.

\section{Conclusion}

These studies demonstrate a concise modular preparation of endocyclic allene 25 under mild reaction conditions. This seven step route gives access to a model system for a synthetic strategy that aims to access the structure space represented by a variety of germacrane natural products, including the vernonia isolates. Computational studies suggest that the diene scaffold may be suitable for further structural modification and adopt the stereoelectronic arrangement necessary for $\mathrm{C}-\mathrm{C}$ fragmentation. Further studies will be reported in due course.

\section{Experimental}

Preparation of endocyclic allene 25: In a $25 \mathrm{~mL}$ flame-dried flask, vinyl triflate 24 (157 mg, $0.408 \mathrm{mmol}$, azeotroped with toluene) was suspended in dry THF $(13 \mathrm{~mL})$. TBAF $(0.4 \mathrm{~mL}$, $0.4 \mathrm{mmol}, 1.0 \mathrm{M}$ in THF, stored over molecular sieves for $>24$ h) was added dropwise. After $10 \mathrm{~min}$, the reaction was quenched by satd. $\mathrm{NH}_{4} \mathrm{Cl}(\mathrm{aq})(15 \mathrm{~mL})$ and partitioned against and washed with ethyl acetate $(3 \times 15 \mathrm{~mL})$. The organic fractions were combined, washed with satd. $\mathrm{NaCl}(\mathrm{aq})(15 \mathrm{~mL})$, dried $\left(\mathrm{Na}_{2} \mathrm{SO}_{4}\right)$, filtered, concentrated in vacuo, and purified by FCC (5\% ethyl acetate/hexane) to give 25 (43 $\mathrm{mg}, 64 \%$ ) as a colorless oil. $R_{\mathrm{f}} 0.08$ ( $1 \%$ ethyl acetate/hexane); IR (neat) $v_{\max }$ 2975, 2903, 2851, 1964, 1693, 1440, $1400 \mathrm{~cm}^{-1} ;{ }^{1} \mathrm{H}$ NMR (400 $\left.\mathrm{MHz}, \mathrm{CDCl}_{3}\right) \delta 6.25(\mathrm{dd}, J=11.9,2.2 \mathrm{~Hz}, 1 \mathrm{H}), 5.70(\mathrm{td}, J=$ $11.7,4.2 \mathrm{~Hz}, 1 \mathrm{H}), 4.95-4.85(\mathrm{~m}, 1 \mathrm{H}), 2.70-2.57(\mathrm{~m}, 2 \mathrm{H})$,
2.42-2.15 (m, 5H), $1.76(\mathrm{ddt}, J=14.7,12.1,2.2 \mathrm{~Hz}, 1 \mathrm{H}), 1.63$ $(\mathrm{d}, J=2.8 \mathrm{~Hz}, 3 \mathrm{H}) ;{ }^{13} \mathrm{C} \mathrm{NMR}\left(101 \mathrm{MHz}, \mathrm{CDCl}_{3}\right) \delta 205.90$, 202.06, 140.21, 132.05, 97.82, 89.33, 41.94, 32.71, 26.71, 26.05, 19.93; ESIMS $m / z$ : $[\mathrm{M}+\mathrm{Na}]^{+}$calcd for $\mathrm{C}_{11} \mathrm{H}_{14} \mathrm{NaO}$, 185.1; found, 185.0 .

\section{Supporting Information}

\section{Supporting Information File 1}

General experimental methods and analytical data, ${ }^{1} \mathrm{H}$ and

${ }^{13} \mathrm{C}$ NMR spectra of compounds $\mathbf{1 8}-\mathbf{2 5}$ and computed structural coordinates for entries $1-5$ in Table 1 .

[http://www.beilstein-journals.org/bjoc/content/ supplementary/1860-5397-7-104-S1.pdf]

\section{Acknowledgements}

Financial support from the NIH (GM-078145) is gratefully acknowledged.

\section{References}

1. Krause, N.; Hoffmann-Röder, A. Allenic Natural Products and Pharmaceuticals. In Modern Allene Chemistry; Krause, N.; Hashmi, A. S. K., Eds.; Wiley-VCH: Weinheim, Germany, 2004; Vol. 2, pp 997-1040. doi:10.1002/9783527619573.ch18

2. Maoka, T.; Akimoto, N.; Terada, Y.; Komemushi, S.; Harada, R.; Sameshima, N.; Sakagami, Y. J. Nat. Prod. 2010, 73, 675-678. doi:10.1021/np100021u

Since 2003, more than 70 additional allene-containing natural products have been reported, see this reference and the following three references for example.

3. Liu, L.; Liu, S.; Chen, X.; Guo, L.; Che, Y. Bioorg. Med. Chem. 2009, 17, 606-613. doi:10.1016/j.bmc.2008.11.066

4. Zhang, F.; Liu, S.; Lu, X.; Guo, L.; Zhang, H.; Che, Y. J. Nat. Prod. 2009, 72, 1782-1785. doi:10.1021/np900512k

5. Hu, G.; Liu, K.; Williams, L. J. Org. Lett. 2008, 10, 5493-5496. doi:10.1021/ol802338z

6. Bohlmann, F.; Jakupovic, J.; Gupta, R. K.; King, R. M.; Robinson, H. Phytochemistry 1981, 20, 473-480. doi:10.1016/S0031-9422(00)84169-2

7. Bohlmann, F.; Zdero, C.; King, R. M.; Robinson, H. Phytochemistry 1982, 21, 695-699. doi:10.1016/0031-9422(82)83168-3

8. Jakupovic, J.; Schmeda-Hirschmann, G.; Schuster, A.; Zdero, C.; Bohlmann, F.; King, R. M.; Robinson, H.; Pickardt, J. Phytochemistry 1986, 25, 145-158. doi:10.1016/S0031-9422(00)94520-5

9. Blomquisrt, A. T.; Burge, R. E., Jr.; Sucsy, A. C. J. Am. Chem. Soc. 1952, 74, 3636-3642. doi:10.1021/ja01134a051 For representative examples of allene synthesis methods applicable to the preparation of endocyclic allenes see this reference and the following seven references.

10. Price, J. D.; Johnson, R. P. Tetrahedron Lett. 1986, 27, 4679-4682. doi:10.1016/S0040-4039(00)85036-4

11. Tolbert, L. M.; Islam, M. N.; Johnson, R. P.; Loiselle, P. M.; Shakespeare, W. C. J. Am. Chem. Soc. 1990, 112, 6416-6417. doi:10.1021/ja00173a050 
12. Brody, M. S.; Williams, R. M.; Finn, M. G. J. Am. Chem. Soc. 1997, 119, 3429-3433. doi:10.1021/ja962868o

13. Thorand, S.; Vögtle, F.; Krause, N. Angew. Chem., Int. Ed. 1999, 38, 3721-3723.

doi:10.1002/(SICI)1521-3773(19991216)38:24<3721::AID-ANIE3721>3 .0.CO;2-9

14. Ogasawara, M.; Okada, A.; Nakajima, K.; Takahashi, T. Org. Lett. 2009, 11, 177-180. doi:10.1021/ol802280c

15. Kolakowski, R. V.; Manpadi, M.; Zhang, Y.; Emge, T. J.; Williams, L. J. J. Am. Chem. Soc. 2009, 131, 12910-12911. doi:10.1021/ja906189h

16. Xi, C.; Yan, X.; You, W.; Takahashi, T. Angew. Chem., Int. Ed. 2009, 48, 8120-8123. doi:10.1002/anie.200904255

17. Fraga, B. M. Nat. Prod. Rep. 2010, 27, 1681-1708. doi:10.1039/c0np00007h

18. Li, Y.; Wu, Y.-Q.; Du, X.; Shi, Y.-P. Planta Med. 2003, 69, 782-784. doi:10.1055/s-2003-42777 See for diepoxygermacrane.

19. Wang, F.; Yang, K.; Ren, F.-C.; Liu, J.-K. Fitoterapia 2009, 80, 21-24. doi:10.1016/j.fitote.2008.09.009 See for carabrolactone A.

20. Tiuman, T. S.; Ueda-Nakamura, T.; Cortez, D. A. G.; Dias Filho, B. P.; Morgado-Diaz, J. A.; de Souza, W.; Nakamura, C. V. Antimicrob. Agents Chemother. 2005, 49, 176-182. doi:10.1128/AAC.49.11.176-182.2005 See for parthenolide.

21. Shen, Y.-C.; Lo, K.-L.; Kuo, Y. H.; Khalil, A. T. J. Nat. Prod. 2005, 68, 745-750. doi:10.1021/np040214k See for eupaheliangolide $A$.

22. Babady-Bila; Kilonda, A.; Mihigo, S.; Lohohola, O.; Tshibey, T. S.; Compernolle, F.; Toppet, S.; Hoornaert, G. J. Eur. J. Org. Chem. 2003, 123-127. doi:10.1002/1099-0690(200301)2003:1<123::AID-EJOC123>3.0.CO;2B See for potamopholide.

23. Yang, Y.-L.; Chang, S.-M.; Wu, C.-C.; Hsieh, P.-W.; Chen, S.-L.; Chang, F.-R.; Hung, W.-C.; Issa, H. H.; Wu, Y.-C. J. Nat. Prod. 2007, 70, 1761-1765. doi:10.1021/np070331q See for spicatolide $\mathrm{G}$.

24. Khan, S. I.; Abourashed, E. A.; Khan, I. A.; Walker, L. A. Planta Med. 2003, 69, 1009-1012. doi:10.1055/s-2003-45147

25. Li, N.; Wu, J.-I.; Hasegawa, T.; Sakai, J.-i.; Bai, L.-m.; Wang, L.-y.; Kakuta, S.; Furuya, Y.; Ogura, H.; Kataoka, T.; Tomida, A.; Tsuruo, T.; Ando, M. J. Nat. Prod. 2007, 70, 998-1001. doi:10.1021/np070089n

26. Triana, J.; López, M.; Rico, M.; González-Platas, J.; Quintana, J.; Estévez, F.; León, F.; Bermejo, J. J. Nat. Prod. 2003, 66, 943-948. doi:10.1021/np020390y

27. Bruno, M.; Rosselli, S.; Maggio, A.; Raccuglia, R. A.; Napolitano, F.; Senatore, F. Planta Med. 2003, 69, 277-281. doi:10.1055/s-2003-38491

28. Drahl, M. A.; Akhmedov, N. G.; Williams, L. J. Tetrahedron Lett. 2011, 52, 325-328. doi:10.1016/j.tetlet.2010.11.050 See for an integrated routing strategy in another series.

29. Katukojvala, S.; Barlett, K. N.; Lotesta, S. D.; Williams, L. J. J. Am. Chem. Soc. 2004, 126, 15348-15349. doi:10.1021/ja044563c

30. Ghosh, P.; Lotesta, S. D.; Williams, L. J. J. Am. Chem. Soc. 2007, 129, 2438-2439. doi:10.1021/ja068813w

31. Lotesta, S. D.; Hou, Y.; Williams, L. J. Org. Lett. 2007, 9, 869-872. doi:10.1021/ol063087n

32. Wang, Z.; Shangguan, N.; Cusick, J. R.; Williams, L. J. Synlett 2008, 213-216. doi:10.1055/s-2007-1000866
33. Ghosh, P.; Cusick, J. R.; Inghrim, J.; Williams, L. J. Org. Lett. 2009, 11, 4672-4675. doi:10.1021/ol901948d

34. Ghosh, P.; Zhang, Y.; Emge, T. J.; Williams, L. J. Org. Lett. 2009, 11, 4402-4405. doi:10.1021/ol901755a

35. Zhang, Y.; Cusick, J. R.; Ghosh, P.; Shangguan, N.; Katukojvala, S.; Inghrim, J.; Emge, T. J.; Williams, L. J. J. Org. Chem. 2009, 74, 7707-7714. doi:10.1021/jo901320f

36. Joyasawal, S.; Lotesta, S. D.; Akhmedov, N. G.; Williams, L. J. Org. Lett. 2010, 12, 988-991. doi:10.1021/ol902984e

37. Sharma, R.; Manpadi, M.; Zhang, Y.; Kim, H.; Ahkmedov, N. G.; Williams, L. J. (accepted).

38. Zhang, Y.; Lotesta, S. D.; Emge, T. J.; Williams, L. J. Tetrahedron Lett. 2009, 50, 1882-1885. doi:10.1016/j.tetlet.2009.02.017 (And references cited therein.)

39. Kamijo, S.; Dudley, G. B. J. Am. Chem. Soc. 2005, 127, 5028-5029. doi:10.1021/ja050663m

Isomeric vinyl triflates have been used to generate alkynes. For the original reports, see this reference and the following two references.

40. Kamijo, S.; Dudley, G. B. J. Am. Chem. Soc. 2006, 128, 6499-6507. doi:10.1021/ja0608085

41. Tummatorn, J.; Dudley, G. B. Org. Lett. 2011, 13, 1572-1575. doi:10.1021/ol2003308

42. Bosch, M. P.; Camps, F.; Coll, J.; Guerrero, A.; Tatsuoka, T.; Meinwald, J. J. Org. Chem. 1986, 51, 773-784. doi:10.1021/jo00356a002

See for compound 15, which was prepared in a three step synthesis from the Wieland-Miescher ketone.

43. Eschenmoser, A.; Frey, A. Helv. Chim. Acta 1952, 35, 1660-1666. doi:10.1002/hlca.19520350532 See for the original $\mathrm{C}-\mathrm{C}$ fragmentation.

44. Clayton, R. B.; Henbest, H. B. Chem. Ind. 1953, 1315-1316.

45. Clayton, R. B.; Henbest, H. B.; Smith, M. J. Chem. Soc. 1957, 1982-1993. doi:10.1039/jr9570001982

46. Wharton, P. S.; Hiegel, G. A. J. Org. Chem. 1965, 30, 3254-3257. doi:10.1021/jo01020a537

47. Tenud, L.; Farooq, S.; Seibl, J.; Eschenmoser, A. Helv. Chim. Acta 1970, 53, 2059-2069. doi:10.1002/hlca.19700530816

48. Beak, P. Acc. Chem. Res. 1992, 25, 215-222. doi:10.1021/ar00017a002

49. Gaussian 03, Revision E.01; Gaussian, Inc.: Wallingford CT, 2004.

50. Becke, A. D. J. Chem. Phys. 1993, 98, 5648-5652. doi:10.1063/1.464913

51. Lee, C.; Yang, W.; Parr, R. G. Phys. Rev. B 1988, 37, 785-789. doi:10.1103/PhysRevB.37.785

52. Vosko, S. H.; Wilk, L.; Nusair, M. Can. J. Phys. 1980, 58, 1200-1211. doi:10.1139/p80-159

53. Stephens, P. J.; Devlin, F. J.; Chabalowski, C. F.; Frisch, M. J. J. Phys. Chem. 1994, 98, 11623-11627. doi:10.1021/j100096a001

54. Ditchfield, R.; Hehre, W. J.; Pople, J. A. J. Chem. Phys. 1971, 54, 721-728.

55. Hariharan, P. C.; Pople, J. A. Mol. Phys. 1974, 27, 209-214. doi:10.1080/00268977400100171

56. Krishnan, R.; Binkley, J. S.; Seeger, R.; Pople, J. A. J. Chem. Phys. 1980, 72, 650-654.

57. McLean, A. D.; Chandler, G. S. J. Chem. Phys. 1980, 72, 5639-5648. doi:10.1063/1.438980

58. Clark, T.; Chandrasekhar, J.; Spitznagel, G. W.; v. Ragué Schleyer, P. J. Comput. Chem. 1983, 4, 294-301. doi:10.1002/jcc.540040303 
59. Dihedral angles for representative structures calculated with the more diffuse (and more computationally demanding) basis set $6-311+g(2 d, 2 p)$ were $\pm 1^{\circ}$.

60 . See Supporting Information File 1 for computed structure coordinates.

61. However, a saturated derivative of this cis-hydrindane failed to fragment under identical conditions.

62. We speculate that the deviation from planarity is an indication of electrostatic stabilization of the alkoxide, which if relevant experimentally, could compromise the facility of the $\mathrm{C}-\mathrm{C}$ fragmentation.

63. Lakhrissi, Y.; Taillefumier, C.; Chrétien, F.; Chapleur, Y. Tetrahedron Lett. 2001, 42, 7265-7268.

doi:10.1016/S0040-4039(01)01531-3

64. Matsumoto, M.; Kuroda, K. Tetrahedron Lett. 1980, 21, 4021-4024. doi:10.1016/S0040-4039(00)92860-0

65. Stork, G.; Zhao, K. Tetrahedron Lett. 1989, 30, 2173-2174. doi:10.1016/S0040-4039(00)99640-0

66. See Table 1 in Supporting Information File 1.

67. Trost, B. M.; Pinkerton, A. B. J. Am. Chem. Soc. 2002, 124, 7376-7389. doi:10.1021/ja011426w

68. Suzuki, K.; Takayama, H. Org. Lett. 2006, 8, 4605-4608. doi:10.1021/ol061908i

69 . This reaction was accompanied by silylenol ether byproduct formation.

\section{License and Terms}

This is an Open Access article under the terms of the Creative Commons Attribution License

(http://creativecommons.org/licenses/by/2.0), which permits unrestricted use, distribution, and reproduction in any medium, provided the original work is properly cited.

The license is subject to the Beilstein Journal of Organic Chemistry terms and conditions:

(http://www.beilstein-journals.org/bjoc)

The definitive version of this article is the electronic one which can be found at: doi:10.3762/bjoc.7.104 